\title{
Selection Factors of Mobile Social Network Games: Focusing on the Playing Types
}

\author{
Tae-Hoon Kang ${ }^{1}$, Boo-Yun Cho ${ }^{* 2}$, Min-Cheol Hyun ${ }^{3}$ and Jae-young Kim ${ }^{4}$ \\ ${ }^{1,2,3}$ Department of Business Administration, Jeju National University 66 \\ Jejudaehak-Ro Jeju-Si Jeju-Do, 690-756, Republic of Korea \\ thkang06@naver.com; bycho@jejunu.ac.kr; jejunuhmc@naver.com \\ ${ }^{2}$ Division of Business Administration, Korea University, 2511 Sejong-ro, Sejong, \\ 30019, Republic of Korea \\ korean4u@korea.ac.kr
}

\begin{abstract}
With the exponential spread of Mobile phones, the Mobile social hetwork game (hereafter "MSNG") market is rapidly growing. MSNG Service provider can enjoy an enormous success of fast spreading market growth of MSNG, while the have to endure the short product life of its service. Recently, the average usage length is less than three months, and it is getting shortened. Managers have to harvest the profit while investing on the marketing to fuel the market penetration. This study tries to find the attributes to continue the MSNGs considering the different forms of gamg opponents (i.e., machine, individual player, and group players). Resalts based on the 678 respondents present the efficacy of different attributes for the different game opponent settings. Managerial implication and the future research direct have been discussed.
\end{abstract}

Keywords: Mobile social network games, Attributes to continues, forms of game opponents

\section{Introduction}

Due to an increase in smattphones usage, the number of customers who play mobile games is growing. In particular, SNG(Social Network Game), which is linked to Social Network Services, is in the limelight.

SNG is an acronym for "Social Network Game." It is a form of online game which connects users of varrous Social Network Services, including Facebook, Twitter, and Kakaotalk [1].

Recently, with the spread of Smartphones, mobile social network games (hereafter, MSNGs) have been widely accepted by all generations, and take up the spare time of smartphone users. Considering that the smartphone converges information and telecommunication technology together, MSNGs is a promising service sector with rapid market growth [2].

The market scale of MSNGs rapidly develops across the globe. Total world market volume was estimated at $\$ 99.6$ billion in 2016 , and personal screen took up $23.7 \%$ of the market share [3]. According to the market forecast for MSNGs, it will expand to \$6.7 billion in the Korean market alone [4].

Compared with existing PC games or online games, SNG has an advantage in that the users enjoy the games with family or friends, not with unknown strangers. Online games

* Corresponding Author 
pose greater risk of side effects, as it connects users with strangers [2]. While the fast proliferation has been regarded as the advantage of MSNGs, its short product life cycle (hereafter, PLC) with rapid maturity and decline is unfavorable to MSNGs service providers[4]. Recent studies insist that the average length of usage for MSNGs is less than three months and its short PLC is on the rise as risk factors to MSNGs managers [5].

This study intends to identify the attributes to continue the MSNGs. Specifically, we focus on the forms of game opponents. While the opponents of conventional arcade games were the machines, game users can nowadays play with other human players. Moreover they can enjoy the group battle. We assume that the different types of opponents can affect the attributes to continue and build three experimental groups (i.e., individual player vs. machine, individual player vs. individual player, group player vs. group player) in order to compare the mean differences among the groups.

We build the constructs based on the study of the Korea Creative Content Agency (KOCCA). They conducted series of in-depth interviews to build the schema of database for contents business and the game industry was the one of the main sectors. Investors and managers of MSNGs recommended interesting factors of the contents, rewards for the MSNGs, social supports, and technical supports for the game users to continue the MSNGs [6]. So we plan to conduct a survey with high school and university-students as the research population to verify the empirical evidences. The types of gane opponents and users characteristics have been considered to be the moderating variables in this study. We hope to find the different patterns of attributes to continue the MSNGs and deliver the managerial implication to the MSNGs service providen

\section{Literature Review}

\subsection{Mobile Social Network Game (NSAG)}

Requests for research on the onine social-network services (SNSs) has been widely proposed [7]. When online games are distributed through the SNSs (including linked distribution with SNSs), those games are defined as SNGs. MSNG is accepted as a name of social games and generally referred to as a web-based, simple repeated game that is played with the usêrs, based on the relationships formed from the SNS [4]. The business model of MSNGs heavily depends on online advertisement and item sales. Therefore, the mangers have to rapidly expand its user network and maximize the usages of game participants within short PLC, So the factors that attract and maintain the customer are essential to sustaining the MSNGs business[8].

\subsection{Attributes to Select and Continue the Msngs}

Game services providers continue to invest to find the attributes to be selected by the customer. Considering short PLC of MSNGs, the factors to maintain the usages are essentia, too. To introduce a numerous MSNGs, two critical factors should be the in the core in any entertainment services delivery systems. Fun factor of the games and usefulmess of the game content have been identified as the previous advantages of MSNGs [9-10]. For the usage of traditional games, the enjoyment factor is the main issue for the participants of the games [11]. But, the usefulness should be engraved in the mind of each customer, when users pursue the advantages from the content of services delivery systems [12-13].

Most MSNGs deliver the games that provide services based mainly on fun factor and usefulness. So the MSNGs developers consider enjoyable tasks, and providing players with fun and entertainment [14-15]. To give the customer the perception of usefulness, MSNGs should be linked to SNS(Social network services). SNS gives the game participants the connection with the other players and social support from them. So the game users experience the extinction of the relationships with other people and 
communication in virtual reality [7]. Existing studies try to identify the degrees of usefulness and enjoyment perceived by the game users in the different contexts [16].

\section{Research Model}

Existing studies on MSNGs largely concern with gamer's personal traits [17] and his or her behaviours [18]. Game players use SNG to pursue fun. Additionally, some users love to compete with other game players, and the others want to achieve more by challenging themselves to master the game or to get a higher level. Immerging MSNGs, users are absorbed in a fantasy world, and identify themselves with another game character. Sometimes game players of SNG enjoy the interaction with other game participants [17].

Moreover, Korea Creative Content Agency (hereafter 'KOCCA'), with data gathered from interviews with entrepreneurs of mobile game business, proposes content entertainment elements, reward, social support, and technical support as building, components of a mobile game [19].

The model of this study is basically based on the elements of KOCCA. Firs mobile game report of ARC Group asserts that plot or theme is important in orderto attract gamers. Also, it stresses that "appearance" of a game, including color display, sound, graphic, animation and graphic elements, poses critical influences on gamers' continued use of the game content.

According to "White book on Korean game 2005 published by KOCCA, responses showed that "favorite character" and "storyline" were important in choosing mobile game than in other game platforms; thus game characters and story are important factors to be considered in the making of a game.

Hypothesis 1. Perception of content entertainment elements will differ depending on mobile game playing types and group

Second, "reward" in game refers to a proper feaction of an online game to user when he or she has completed a celtain action. It also includes cases in which the enemy perishes by the attack of user, or the power of user's character strengthens when he or she reaches a certain goal.

A fitting reward in online game could promote effective interaction, making the player immerse himself inthe game.

Hypothesis 2. Perception of a reward will differ depending on mobile game playing types and groups.

Third, in choosing which mobile game to play, studies have shown that factors including interaction, reward, and a sense of accomplishment influence user intent to use and continue to use the game. Also, challenge elements were one of the most important factors in mobile games. According to a survey taken by developers of mobile games, social support, challenge, interaction, recognition, and a sense of accomplishment were important factors in mobile game.

Hypothesis 3. Perception of social support will differ depending on mobile game playing types and groups.

Lastly, a study by KOCCA showed that accessibility, handy control, the volume of game contents, and network overload were important factors in technological support of mobile game developers [9].

Generally, system quality is an extent to which the user can use the system efficiently and steadily. It explains the operational efficiency of Information Systems. While system quality has been studied as a success factor of information systems, such outcome is the result of technological factors, which includes turnaround time, currency, accuracy, response time, system flexibility, reliability, and completeness. And accessibility means that anyone could easily access media and use the contents. Conditions that facilitate mobile game use of players are referred to as technological support.

Considering Group to Group play type is in the situation of limited space with numerous participants who want a relatively simple purpose, accessibility and loads for 
game and network would not be so burdensome than that of Person to Person game or Person to Machine play type

Hypothesis 4. Perception of technical support will differ depending on mobile game playing types and groups.

Here we tried to analyze the difference of perception depending on mobile game playing types and groups by extending from the existing study (KOCCA, 2015). This study aims to illustrate the differences in factors of mobile game depending on game playing types and groups with what we found about factors of content entertainment elements, reward, social support, technical support in mobile games.

\section{Research Methodology}

We intend to compare the mean differences among the groups based on two factors. We consider the level of freedom as the first control variable, and collect the data from high school students (lower freedom group) and university students (upper freedon group). Additionally, we hypothesize the differences among the forms of game opponents, and build three types of surveys.

Constructs and the measurements are anchored on the resêarch for the game industry. According to the report from the KOCCA (2015), practitionets in MSNGs suggest four necessary dimensions (i.e., interesting factors of the contents, rewards for the MSNGs, social supports, and technical supports) to develop successful games.

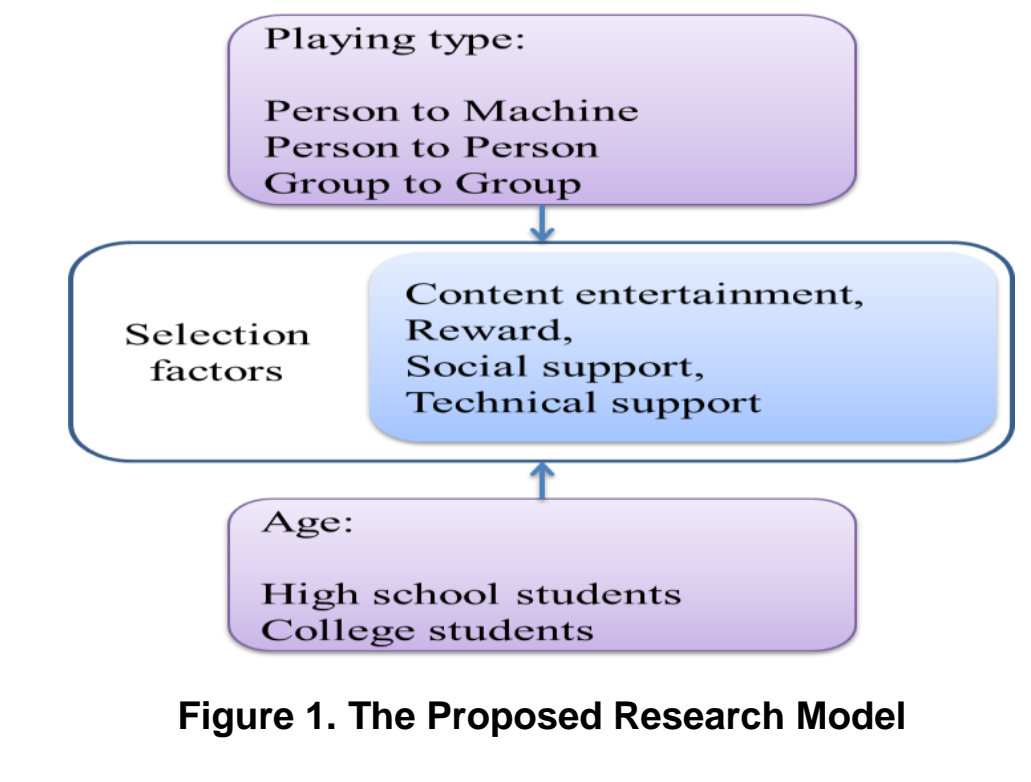

We collected the 677 responses, and plan to apply the ANOVA to compare the differences among the groups.

The population of this study is users who play mobile game continuously. Individual survey question was posed based on the existing literature, and the data were gathered by suryey. In this process, we retrieved a total of 678 surveys. Excluding 10 inappropriate responses, we carried out the analysis with 668 surveys.

Table 1 is the summary of attributes of descriptive statistics of the responses. The results showed that male users are $74.0 \%$ and female users $26.0 \%$. The age group from 16 to 20 were most frequent users, with $58.1 \%$. For academic background, high school students and college students were 50.0\%, respectively. For "Hours of smartphone use," more than 5 hours was the most frequent response, with 22.5\%. For "Hours of mobile game use" less than 30 minutes was the most frequent response, with $64.2 \%$. 
Table 1. Respondent's Information in the Main Survey $(n=668)$

\begin{tabular}{|c|c|c|c|c|c|c|c|}
\hline \multicolumn{2}{|c|}{ Division } & Frequency & Percent & \multicolumn{2}{|c|}{ Division } & Frequency & Percent \\
\hline \multirow{2}{*}{ Gender } & Male & 494 & 74.0 & \multirow{4}{*}{ Age } & $10 \sim 15$ & 4 & 0.6 \\
\hline & Female & 174 & 26.0 & & $16 \sim 20$ & 388 & 58.1 \\
\hline \multirow{2}{*}{\begin{tabular}{|c|} 
Academic \\
Background
\end{tabular}} & $\begin{array}{c}\text { High School } \\
\text { Student }\end{array}$ & 334 & 50.0 & & $21 \sim 25$ & 197 & 29.5 \\
\hline & $\begin{array}{l}\text { College } \\
\text { Student }\end{array}$ & 334 & 50.0 & & $26 \sim 30$ & 79 & 11.8 \\
\hline \multirow{6}{*}{$\begin{array}{c}\text { Hours of } \\
\text { use of } \\
\text { smartphone }\end{array}$} & $\begin{array}{c}\text { Less than } 1 \\
\text { hour }\end{array}$ & 65 & 9.7 & \multirow{6}{*}{$\begin{array}{c}\text { Hours of } \\
\text { use of } \\
\text { mobile } \\
\text { game }\end{array}$} & $\begin{array}{c}\text { Less than } 30 \\
\text { minutes }\end{array}$ & 429 & 64.2 \\
\hline & $1 \sim 2$ hours & 112 & 16.8 & & $\begin{array}{c}31 \text { minutes to } 1 \\
\text { hour }\end{array}$ & 111 & \\
\hline & $2 \sim 3$ hours & 145 & 21.7 & & \begin{tabular}{|c}
1 hour $\sim 1$ hour \\
30 minutes \\
\end{tabular} & 59 & \\
\hline & $3 \sim 4$ hours & 133 & 19.9 & & minutes 2 & & \\
\hline & 4 5 hours & 63 & 9.4 & & & & 7.0 \\
\hline & $\begin{array}{c}\text { More than } 5 \\
\text { hours }\end{array}$ & 150 & 22.5 & & & 668 & 100.0 \\
\hline
\end{tabular}

It has been shown that there is meaningful difference between the perception of content entertainment elements social support, and technological support, depending on mobile game playing types and groups.

According to the analysis, content entertanment elements $(p=0.007)$, reward ( $p=$ $0.034)$, social support $(p=0.001)$, and technical support $(p=0.024)$ were the factors which assumed to influence the differences. And all hypotheses were supported;

Table 2. Results of Analysis

\begin{tabular}{|c|c|c|c|c|c|c|}
\hline Factors & PIay type & Students & Mean & $\begin{array}{l}\text { Standard } \\
\text { deviation }\end{array}$ & $F$ & $\begin{array}{l}\text { Post-hoc } \\
\text { analysis }\end{array}$ \\
\hline \multirow{6}{*}{$\begin{array}{l}\text { Content } \\
\text { ntertainme }\end{array}$} & \multirow{4}{*}{$\begin{array}{l}\text { Personto } \\
\text { Machine } \\
\text { Person to } \\
\text { Person }\end{array}$} & (1) high school & 3.594 & 1.044 & \multirow{6}{*}{$\begin{array}{c}3.226 \\
(p=0.007)\end{array}$} & \multirow{6}{*}{ (3) $>$ (6) } \\
\hline & & (2) college & 3.421 & 0.906 & & \\
\hline & & (3) high school & 3.760 & 0.819 & & \\
\hline & & (4) college & 3.461 & 0.806 & & \\
\hline & Group to & (5) high school & 3.600 & 1.098 & & \\
\hline & Group & (6) college & 3.263 & 0.881 & & \\
\hline \multirow{5}{*}{ Reward } & \multirow{2}{*}{$\begin{array}{l}\text { Person to } \\
\text { Machine }\end{array}$} & (1) high school & 3.678 & 0.969 & \multirow{5}{*}{$\begin{array}{c}2.437 \\
(p=0.034)\end{array}$} & \multirow{5}{*}{$\begin{array}{c}\text { (3) }>\text { (6) } \\
1 \\
\text { (2) }>\text { (6) }\end{array}$} \\
\hline & & (2) college & 3.871 & 0.773 & & \\
\hline & \multirow{2}{*}{$\begin{array}{l}\text { Person to } \\
\text { Person }\end{array}$} & (3) high school & 3.848 & 0.772 & & \\
\hline & & (4) college & 3.714 & 0.769 & & \\
\hline & Group to & (5) high school & 3.788 & 1.057 & & \\
\hline
\end{tabular}




\begin{tabular}{|c|c|c|c|c|c|c|}
\hline & Group & (6) college & 3.490 & 0.968 & & \\
\hline \multirow{6}{*}{$\begin{array}{l}\text { Social } \\
\text { support }\end{array}$} & \multirow{2}{*}{$\begin{array}{l}\text { Person to } \\
\text { Machine }\end{array}$} & (1) high school & 3.552 & 1.024 & \multirow{6}{*}{$\begin{array}{c}4.381 \\
(p=0.001)\end{array}$} & \multirow{6}{*}{$\begin{array}{c}\text { (1) }<\text { (3) } \\
/ \\
>\text { (2), (4), (6) } \\
/ \\
\text { (5) }>\text { (2) }\end{array}$} \\
\hline & & (2) college & 3.357 & 1.025 & & \\
\hline & \multirow{2}{*}{$\begin{array}{l}\text { Person to } \\
\text { Person }\end{array}$} & (3) high school & 3.963 & 0.900 & & \\
\hline & & (4) college & 3.564 & 0.861 & & \\
\hline & \multirow{2}{*}{$\begin{array}{l}\text { Group to } \\
\text { Group }\end{array}$} & (5) high school & 3.815 & 1.166 & & \\
\hline & & (6) college & 3.481 & 0.988 & & \\
\hline \multirow{6}{*}{$\begin{array}{l}\text { Technical } \\
\text { support }\end{array}$} & \multirow{2}{*}{$\begin{array}{l}\text { Person to } \\
\text { Machine }\end{array}$} & (1) high school & 3.645 & 1.062 & \multirow{6}{*}{$\begin{array}{c}2.605 \\
(p=0.024)\end{array}$} & \\
\hline & & (2) college & 3.768 & 0.877 & & \\
\hline & \multirow{2}{*}{$\begin{array}{l}\text { Person to } \\
\text { Person }\end{array}$} & (3) high school & 3.851 & 0.875 & & \\
\hline & & (4) college & 3.721 & 0.851 & & \\
\hline & \multirow{2}{*}{$\begin{array}{l}\text { Group to } \\
\text { Group }\end{array}$} & (5) high school & 3.619 & 1.073 & & \\
\hline & & (6) college & 3.402 & & & \\
\hline
\end{tabular}

If we look closer, the importance of content entertainment elements recorded a higher average in the high school students group than in the college students group. Game Playing type showed, from the highest rank Person to Person, Person to Machine, and Group to Group. In the case of Person to Person, or Person to Machine, the game focuses on challenging the task with various content entertainment elements. In case of Group to Group play, the game focuses more on winning the game -competition between teams and cooperation within team. Accordingly, Person to Person, Person to Machine games put a greater emphasis on the game's story, character, sound (background music), design, and the world within gamethan Group to Group games.

Especially, after doing post-hoc analysis in order to check the significant difference between the groups, we found that high school students who play Person to Person rated the content entertainment elements better than did college students who play Group to Group. The importance of reward in mobile game showed an average value greater than 3.6 in all groups, except the oollege students who use Group to Group play. This shows that in most of cases, re vard is very important in game play.

Regarding the importance of social support, high school students emphasized it more than college students did, and Game Playing Types ranked from Person to Person, Group to Group, to Person to Machine. Unlike in the case of Person to Machine, where the user gains entertainment experience through continuous challenge, cases where interaction is emphasized, such as Person to Person, Group to Group would put greater importance on social-support.

In case of Person to Machine, completing a mission, including quest, or gaining scores, would fuel the challenge. However, Person to Person, Group to Group play provides fun, recognition of members, and a sense of accomplishment through competition.

Technological Support is regarded as a more important element in types like Person to Machine, or Person to Person, where users enjoy various contents in course of clearing the mission, than in Group to Group cases where competition is the primary source of enjoyment.

In Person to Machine, or Person to Person play type, no advisor exists. So, the contents and storyline are more important to persuade the participants. It is similar with that of self -service situation. Without enough information and direction, customers would not be satisfied with that service with the failure of finding right direction 


\section{Conclusion}

While the fast growth of the market is so attractive, short PLC has been considered as the vulnerable point of MSNGs. So, the identification of the attributes for users to continue is the keystone to generate the demand of potential customers under the time limitation to maximize the profits.

This study intends to find the differences for the continuance attributes among the forms of game opponents of MSNGs. Moreover, we strive to investigate the social factors during the game. Results show that the content entertainment, reward, social support, and technical support are the important factors for game users to continue the MSNGs. And those effects would be differentiated by the playing type and age are the factors to make the differences.

Based on the data which have been gathered from those in the late teens and the early, twenties, we suggest some theoretical implication. First, this study proposes the factors for MSNGs users to continue the game. While the usages of MSNGs are skyrocketing, existing studies have been focusing on the online game. Mobile environments let the users invest more time and effort to play the game, and it gives more chances to the game publishers and developers. We recommended four antecedents based on recent interview with the experts in MSNGS, so the identification of those factors would be beneficial in maintaining the incumbent customer. Second, we pay attention to the importance of playing type. Different game opponents request game participants for pursuing different selection factors of MSNGs. Moreover, game developer should consider the differentiated set of game components to fulfill the needs of customets from the different forms of playing types.

Managerial implications are as follows. First, game service providers should pay more attention to deliver Group to Group game to college students. Generally, college students who participate in the Group to Group playing types give lower importance in any selection factors. While Group to Group is the common playing type in online games, it has not been widely accepted by college students, yet. Second, the interesting set of selection factors of reware and technical support needs to be investigated. High school students who play the Person to Person game and college students who enjoy the Person to Machine game puts more weight on reward and technical support than the college students who pâficipate in the Group to Group game. Finally, social support is a more attractive element for the highsschool students in the game with human players, whether it is Group to Group or Person to Person game.

Limitations of thiogearch call for more exploration on the topics of MSNGs. While paying more attention to the form of game opponents, reflection of mobile characteristics is somewhat linited. Considering that the mobility breaks the location barrier of game play, mobile traits should be investigated more in the future researches. We think the age can be the proxy for the level of freedom in playing the proxy MSNGs. Even though the differences were found between the high school and college students, there is no clear explanation for that gap in this study. We look forward to finding the answer in the next tudy.

\section{References}

[1] K. Y. Lee, "The Impact of Perceived Attributes, Usage Habits and Users' Addiction in Continuance of Social Network Game", Korea: DAEHAN Association of Business Administration, (2013).

[2] E. Park, S. Baek, J. Ohm and H. J. Chang, "Determinants of player acceptance of mobile social network games: An application of extended technology acceptance model”, Telematics and Informatics, vol. 31, no. 1, (2014), pp. 3-15.

[3] Newzoo, “2015 2019 Global Games Market Report”, vol. 4, (2016). 
[4] T. H. Kang and H.G. Kim, "A Study of the Precedents and the Dependent Variables on the Boredom of the Mobile Game", The Journal of Internet Electronic Commerce Research, vol. 16, no. 1, (2016), pp. 215-235.

[5] H. G. Kim, "Analysis of Market Trends and Mobile Social Gaming Business Model: Focusing On Japanese Mobile Social Gaming", Journal of The Korea Entertainment Industry Association, vol. 6, no. 4, (2012), pp. 82-92.

[6] T. H. Kang, B. Y. Cho and M. C. Hyun, "Effects of the Forms of Game Opponents towards the Attributes to Continue the MSNGs", Advanced Science and Technology Letters, vol. 127, (2016), pp. 264-266.

[7] P. L. P. Rau, Q. Gao and Y. Ding, "Relationship between the level of intimacy and lurking in online social network services", Computers in Human Behavior, vol. 24, no. 6, (2008), pp. 2757-2770.

[8] T. H. Kang, H. G. Kim and B. Y. Cho, "A Study on the Antecedents of Acquaintances Recommended Actions in the Mobile Social Network Game", Journal of Internet Electronic Commerce Research, vol. 13, no. 2, (2013), pp. 257-281.

[9] D. Y. Wohn, C. Lampe and R. Wash, "The" S" in social network games: Initiating, maintaining, and enhancing relationships", in System Sciences (HICSS), 2011 44th Hawaii International Conference on IEEE, (2011).

[10] N. Yee, "Motivations for play in online games", CyberPsychology \& behavior, vol. 9, no. 6, (2006), pp. $772-775$.

[11] C. T. Klimmt, T. Hartmann and A. Frey, "Effectance and control as determinants of video game enjoyment", Cyberpsychology \& behavior, vol. 10, no. 6, (2007), pp. 845-848.

[12] J. Bourgonjon, M. Valcke, R. Soetaert and T. Schellens, "Students' perceptions about the use of video games in the classroom", Computers \& Education, vol. 54, no. 4, (2010), pp. 1145-1156

[13] A. Millar and D. J. Navarick, "Self-control and choice in humans: Effects of video game playing as a positive reinforcer", Learning and Motivation, vol. 15, no. 2, (1984), pp. 203-218

[14] I. Ha, Y. Yoon, and M. Choi, "Determinants of adoption of mobile games ander mobile broadband wireless access environment", Information \& Management, vol. 44, no. 3, (2007), pp. 276-286.

[15] D. H. Shin and Y.-J. Shin, "Why do people play socia network gane" Computers in Human Behavior, vol. 27, no. 2, (2011), pp. 852-861.

[16] Y. Y. Mun and Y. Hwang, "Predicting the use of web-based Information systems: self-efficacy, enjoyment, learning goal orientation, and the technology aceeptance model", International journal of human-computer studies, vol. 59, no. $4,(2003$ ), pp. $431-449$.

[17] J. Lee, M. Lee and I. H. Choi, "Social network games uncevered: Motivations and their attitudinal and behavioral outcomes", Cyberpsychology, Behavior, and Social Networking, vol. 15, no. 12, (2012), pp. 643-648.

[18] H. Cole and M. D. Griffiths, "Sockal interactions in massively multiplayer online role-playing gamers". CyberPsychology \& Behay or, vol. 10, no. 4, (2007), pp. 575-583.

[19] K. C. C. Agency, "The State and Development Plan for Korea Online Game Industry, in Korea Entertainment System Industry Association”, Korea Entertainment System Industry Association, (2015).

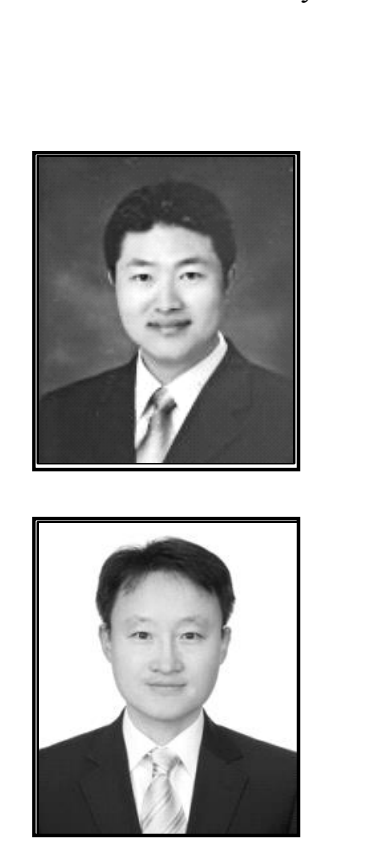

\section{Authors}

Kang Tae-Hoon, February 2015 PhD Jeju National University Graduate School of Business Administration. March 2015-present: Jeju National University Docent.

Cho Boo-Yun, August 2012 (Dr. LSOM), Korea University Department of Business Administration. September 2012-present: Jeju National University Professor. 


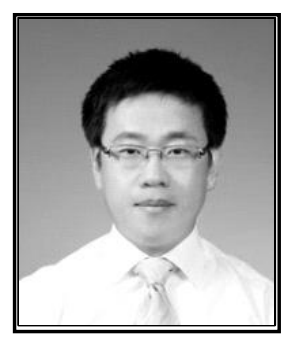

Hyun Min-Cheol, March 2013-present: PhD student Jeju National University Graduate School of Business Administration.

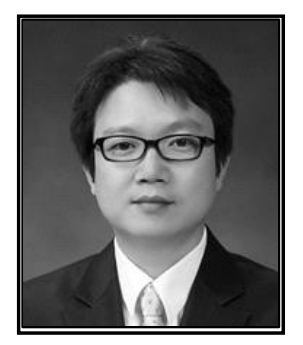

Kim Jae-Young, February 2013 (Dr. MS/IS), Korea University Department of Business Administration. March 2015-present: Korea University Assistant Professor

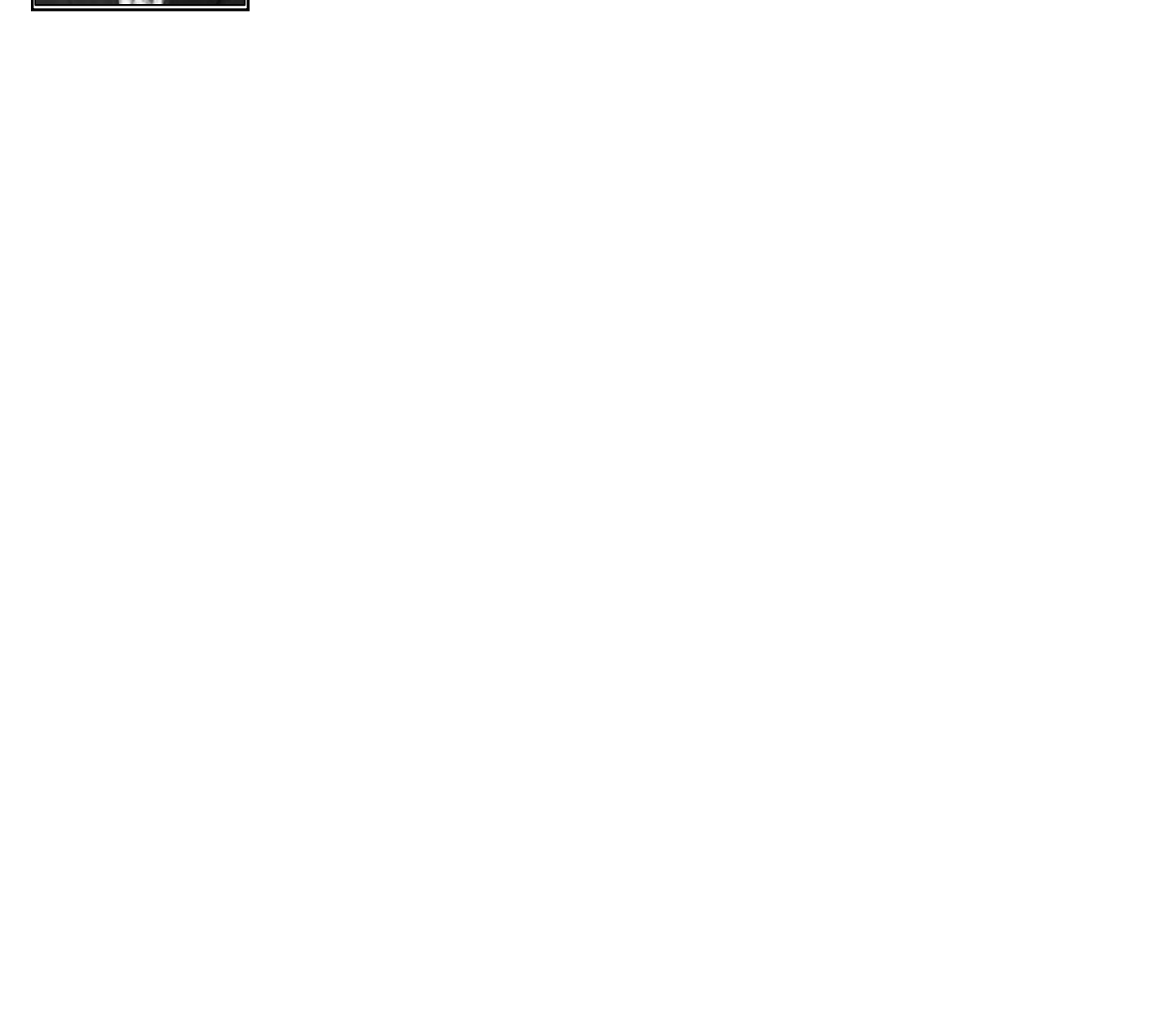




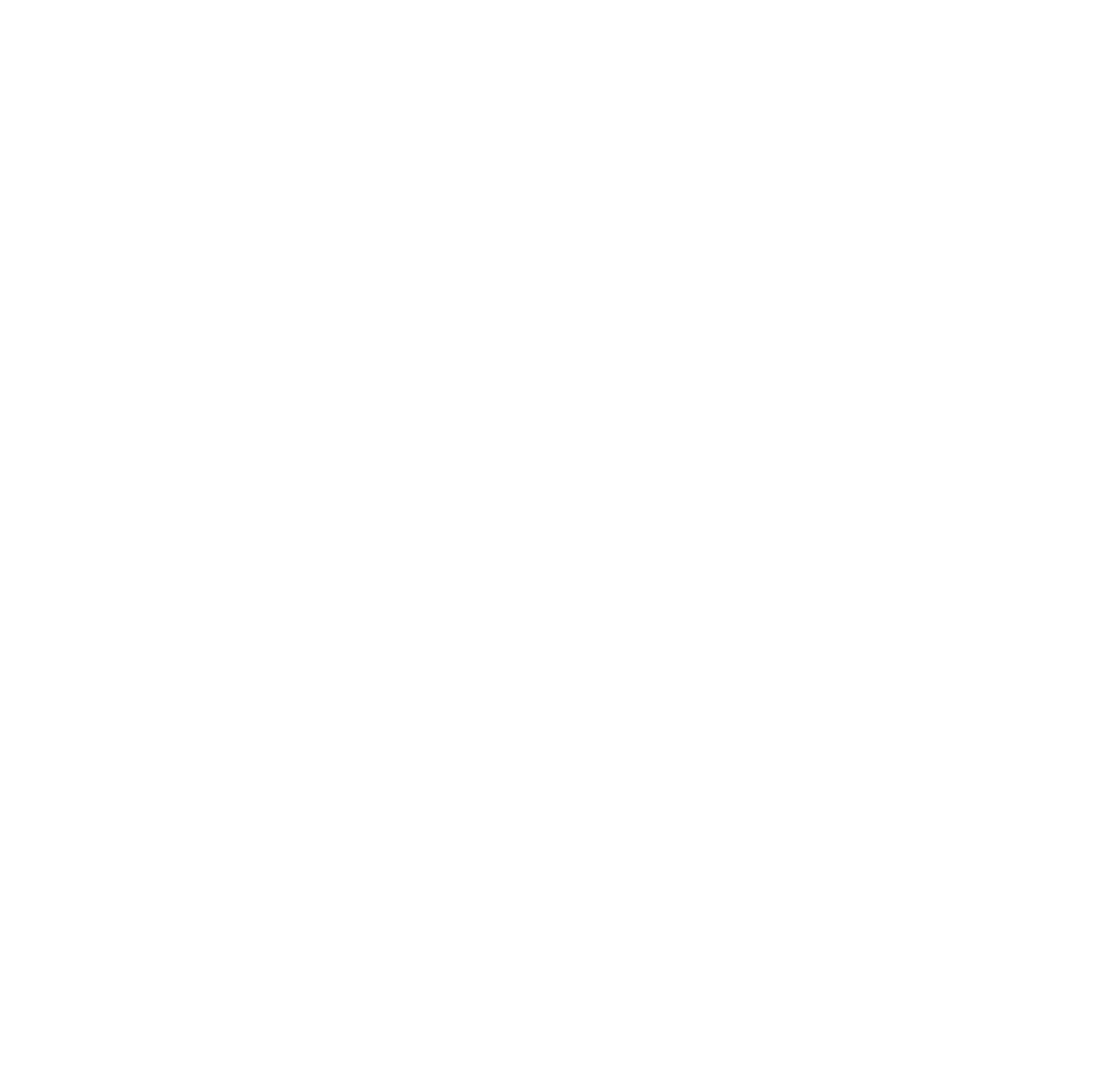

